\title{
STRATEGI KOPERASI SYARIAH SIDOGIRI CABANG PEMBANTU YOSOWILANGUN DALAM MEMBERDAYAKAN MASYARAKAT EKONOMI LEMAH DI DESA YOSOWILANGUN LOR KECAMATAN YOSOWILANGUN KABUPATEN LUMAJANG
}

\author{
Fidyah Jayatri ${ }^{1}$, Dwi Yanuarindah Putri ${ }^{2}$ \\ ${ }^{1}$ Program Studi Pendidikan Ekonomi, STKIP PGRI Lumajang \\ fidyah.jaya3@gmail.com \\ 2Program Studi Pendidikan Ekonomi, STKIP PGRI Lumajang \\ dwi.y.putri@gmail.com
}

\begin{abstract}
Syariah cooperatives are cooperatives that are managed using syariah principles. The findings of observations from the Sidogiri Syariah cooperative research Capem Yosowilangun prioritize the convenience of interacting with members, especially in financing activities that are experiencing difficulties. Form of business development for members, the Sidogir Cooperative Capem Yosowilangun uses a profit sharing system that is in accordance with the teachings of Islamic law and does not use interest rewards like conventional banks or cooperatives in general. This type of research is a qualitative research with a phenomenological approach. The informants of this research are the manager of the Sidogiri Cooperative and the people of Yosowilangun Lor Village, Yosowilangun District, Lumajang Regency who are members of the cooperative. Data collection uses observation techniques, in-depth interviews, and documentation. The data analysis technique used is data reduction, data display, verification of research data. Data validity uses credibility, transfersibility, dependability, and confirmability. The results showed that (1) Community's understanding of Islamic cooperatives was good where the community was able to explain that the form of management of Islamic cooperatives and (2) the strategy of Islamic cooperatives in empowering a weak economy community was demonstrated by making efforts to pick up the ball to members / customers whose economies were weak to do business or entrepreneurship. Suggestions (1) For Economic Education Study Program STKIP PGRI Lumajang is expected to be
\end{abstract}


able to provide references relating to syariah cooperative strategies in empowering weak economic communities. (2) Cooperative managers are expected to be able to improve services to the community so that in the future they will be able to introduce Islamic economics to a wider community. Last (3) Cooperative members are expected to be able to choose cooperative products according to their needs in an effort to improve their economy which is expected to contribute to the promotion and introduction of syariah economy to the wider community.

Keywords: Shariah Cooperative Strategy, Public Development, Weak Economy

\begin{abstract}
Abstrak
Koperasi syariah merupakan koperasi yang dikelola menggunakan prinsipprinip syariah. Temuan observasi penelitian koperasi syariah Sidogiri Capem Yosowilangun mengutamakan kenyamanan berinteraksi dengan anggota terutama dalam kegiatan pembiayaan yang mengalami kesulitan. Bentuk pengembangan usaha anggota, Koperasi Sidogir Capem Yosowilangun menggunakan sistem bagi hasil yang sesuai dengan ajaran syariat Islam serta tidak menggunakan imbalan bunga seperti bank atau koperasi konvensional pada umumnya. Jenis penelitian ini merupakan penelitian kualitatif dengan pendekatan fenomenologi. Informan penelitian ini yaitu pengelola koperasi sidogiri dan masyarakat Desa Yosowilangun Lor Kecamatan Yosowilangun Kabupaten Lumajang yang menjadi anggota koperasi. Pengumpulan data menggunakan teknik observasi, wawancara mendalam, dan dokumentasi. Teknis analisis data yang di gunakan yaitu dengan reduksi data, display data, verifikasi data penelitian. Keabsahan data menggunakan kredibility, transfersibility, dependibility, dan konfirmability. Hasil penelitian menunjukkan bahwa (1) Pemahaman masyarakat terhadap koperasi syariah sudah baik dimana masyarakat mampu menjelaskan bahwa bentuk pengelolaan koperasi syariah dan (2) strategi koperasi syariah dalam memberdayakan masyarakat ekonomi lemah ditunjukkan dengan melakukan
\end{abstract}


upaya jemput bola terhadap anggota/nasabah yang perekonomiannya lemah untuk berbisnis atau berwirausaha. Saran (1) Bagi Prodi Pendidikan Ekonomi STKIP PGRI Lumajang diharapkan mampu memberikan referensi yang berkaitan dengan strategi koperasi syariah dalam memberdayakan masyarakat ekonomi lemah. (2) Bagi pengelola koperasi dihararapkan dapat meningkatkan pelayanan kepada masyarakat sehingga kedepan mampu memperkenalkan ekonomi syariah kepada masyarakatt lebih luas. Terakhir (3) Bagi anggota koperasi diharapkan mampu memilih produk koperasi sesuai kebutuhannya dalam upaya meningkatkan perekonomian mereka yang diharapkan dapat ikut andil dalam mengangkat dan memperkenalkan ekonomi syariah kepada masyarakat lebih luas.

Kata kunci : Strategi Koperasi Syariah, Pemberdayaan Masyarakat, Ekonomi Lemah 


\section{A. PENDAHULUAN}

Perkembangan lembaga keuangan berbasis ekonomi islam di Indonesia berkembang cukup pesat. Salah satu lembaga keuangan yang masih populer di masyarakat yaitu koperasi. Koperasi berbasis ekonomi islam lebih dikenal dengan sebutan koperasi syariah. Koperasi syariah didirikan untuk meningkatkan kesejahteraan bersama antara anggota koperasi pada khususnya dan masyarakat pada umumnya, serta turut membangun tatanan perekonomian yang berbasis kerakyatan dan berkeadilan serta sesuai dengan prinsip-prinsip Islam. Pangsa pasar koperasi syariah yang terus meningkat menjadikan koperasi syariah semakin menjadi primadona dikalangan masyarakat untuk melakukan kegiatan ekonomi bertujuan meningkatkan perekonomiannya.

Berkaitan dengan peranan koperasi syaiah tersebut, peneliti tertarik untuk mengetahui lebih dalam strategi Koperasi Sidogiri Cabang Pembantu Yosowilangun yang mana eksistensi dari peran koperasi ini cukup populer di masyarakat Yosowilangun. Anggota dari koperasi ini pun banyak dari golongan masyarakat ekonomi lemah. Salah satu kegiatan keuangan yang sangat tampak dalam menerapkan prinsip Islam bagi Koperasi Syariah Sidogiri Cabang Pembantu Yosowilangun adalah kegiatan pembiayaan. Menurut Sumiyanto (2008:165) pembiayaan merupakan aktivitas penyaluran dana yang terkumpul kepada anggota pengguna dana, memilih jenis usaha yang akan dibiayai agar diperoleh jenis usaha yang produktif, menguntungkan dan dikelola oleh anggota yang jujur dan bertanggung jawab.

Berdasarkan Peraturan Menteri Keuangan RI Nomor 219/PMK.05/2013 tentang Kebijakan Akuntansi Pembiayaan, mendefinisikan pembiayaan (financing) sebagai setiap penerimaan yang perlu dibayar kembali dan/ atau pengeluaran yang akan diterima kembali, baik pada tahun anggaran bersangkutan maupun tahun-tahun anggaran berikutnya, yang dalam penganggaran pemerintah terutama dimaksudkan untuk menutup defisit atau memanfaatkan surplus anggaran. Jadi 
dari definisi diatas dapat disimpulkan bahwa pembiayaan (financing) adalah kegiatan penyaluran dana dari pemberi dana (kreditur) kepada penerima dana (debitur) dalam bentuk kredit yang wajib dibayar kembali oleh pihak debitur melalui angsuran pada waktu tertentu. Pembiayaan dalam Islam sangat berbeda dengan pembiayaan dalam lembaga keuangan konvensional, yang terletak dalam sistem operasionalnya. Sistem simpan pinjam dengan pola syari'ah Koperasi Syariah Sidogiri Capem Yosowilangun menggunakan imbalan bagi hasil untuk anggotanya.

Pelayanan jasa simpanannya berupa bentuk simpanan yang terikat dan tidak terikat, atas jangka waktu dan syarat-syarat tertentu dalam penyetoran, dan penarikannya. Koperasi Syariah Sidogiri Capem Yosowilangun mengutamakan kenyamanan berinteraksi dengan anggota terutama dalam kegiatan pembiayaan yang mengalami kesulitan. Dalam pengembangan usaha anggota, koperasi tersebut menggunakan imbalan bagi hasil yang sesuai dengan ajaran syariah Islam serta tidak menggunakan imbalan bunga sebagaimana bank atau koperasi konvensional pada umumnya.

Menurut Blocher, Stout, Juras, \& Cokins (2013:15) strategi didefinisikan sebagai sebuah perencanaan yang memanfaatkan sumber daya untuk mencapai tujuan yang berkelanjutan didalam lingkungan yang kompetitif. Lebih lanjut Hitt, Ireland and Hoskisson dalam Afuah (2009:29) memaparkan bahwa strategi adalah serangkaian komitmen dan tindakan yang terintegrasi dan terkoordinasi yang dibentuk untuk memanfaatkan kompetensi inti dari perusahaan guna meraih keunggulan kompetitif. Berkaitan dengan itu maka yang dimaksud dengan strategi koperasi syariah adalah strategi merupakan rangkaian tindakan dengan memanfaatkan kekuatan dan sumber daya yang dimiliki koperasi dalam rangka mencapai tujuan dan target koperasi.

Menurut Abdul Hamid (2008:47) koperasi syariah merupakan koperasi yang aktivitas usahanya menghimpun dan menyalurkan dana dari/kepada anggota atau 
calon anggota dengan sistem mudhorabah (bagi hasil) atau murabahah (jual beli) yang dijamin sah menurut syari'ah dan tidak bertentangan dengan peraturan perundang-undangan negara Republik Indonesia, dan transaksi yang diterapkan dalam aktivitas BMT tidak mengandung unsur riba yang dilarang menurut syari'ah. Koperasi Syariah adalah koperasi yang aktivitas usahanya adalah menghimpun dan menyalurkan dana dari/kepada anggota atau calon anggota dengan sisitem mudhorabah (bagi hasil) atau murabahah (jual beli) yang dijamin sah menurut syari'ah dan tidak bertentangan dengan peraturan perundang-undangan negara Republik Indonesia, dan transaksi yang diterapkan dalam aktivitas BMT tidak mengandung unsur riba yang dilarang menurut syari'ah. Berdasarkan paparan tersebut maka indikator tentang koperasi syariah sebagai berikut.

1. Koperasi yang memiliki konsep kerjasama tidak ada sisrtem bunga. yaitu penghimpunan, pengelolaan serta penyaluran dana untuk suatu tujuan profit menggunakan pola bagi hasil.

2. Akad awal dalam menjalin kerjasama dengan anggota dilakukan dengan melalui kesepakatan bersama, yaitu besar atau kecilnya persentase bagi hasil ditentukan sesuai dengan akad awal yang telah disepakati bersama.

3. Kerugian kerjasama ditanggung bersama yang mana kerjasama antara anggota dengan koperasi mengalami kerugian, maka kerugian akan ditanggung bersama.

Lebih lanjut koperasi syariah sidogiri capem Yosowilangun memiliki tujuan utama yaitu peningkatan ekonomi lemah masyarakat yang menjadi anggota koperasi melalui pemberdayaan anggota koperasi. Pemberdayaan merupakan sebuah upaya dalam membangun kemampuan masyarakat, dengan cara mendorong, memotivasi, membangkitkan kesadaran akan potensi yang dimiliki dan berupaya untuk mengembangkan potensi itu menjadi tindakan nyata (Haris, Abdul 2013:42). Lebih lanjut adapun beberapa tahap pelaksanaan kegiatan pemberdayaan menurut Muslim, Azis (2012:33-34) yaitu, 
1. Pertama, tahap penyadaran dan pembentukan perilaku. Perlu membentuk kesadaran menuju perilaku sadar dan peduli sehingga merasa membutuhkan peningkatan kapasitas diri. Dalam tahapan ini pihak yang menjadi sasaran pemberdayaan harus disadarkan mengenai perlu adanya perubahan untuk merubah keadaan agar dapat sejahtera.

2. Kedua, tahap trasformasi pengetahuan dan kecakapan ketrampilan, dalam hal ini perlu adanya pembelajaran mengenai berbagai pengetahuan, dan kecakapan ketrampilan untuk mendukung kegiatan pemberdayaan yang dilaksanakan. Dengan adanya pengetahuan, dan kecakapan ketrampilan maka sasaran dari pemberdayaan akan memiliki pengetahuan, kemampuan, dan ketrampilan yang menjadi nilai tambahan dari potensi yang dimiliki.

3. Ketiga, tahap peningkatan kemampuan intelektual dan kecakapan ketrampilan. Dalam tahapan peningkatan kemampuan intelektual dan ketrampilan ini sasaran pemberdayaan diarahkan untuk lebih mengembangkan kemampuan yang dimiliki, meningkatkan kemampuan dan kecakapan ketrampilan yang pada nantinya akan mengarahkan pada kemandirian.

\section{B. METODE PENELITIAN}

Jenis penelitian ini adalah penelitian menggunakan jenis penelitian kualitatif dengan pendekatan fenomenologi. Informan penelitian ini yaitu pengelola koperasi sidogiri dan masyarakat Desa Yosowilangun Lor Kecamatan Yosowilangun Kabupaten Lumajang yang menjadi anggota koperasi. Pengumpulan data menggunakan teknik observasi, wawancara mendalam, dan dokumentasi. Teknis analisis data yang di gunakan yaitu dengan reduksi data, display data, verifikasi data penelitian. Keabsahan data menggunakan kredibility, transfersibility, dependibility, dan konfirmability. 


\section{HASIL DAN PEMBAHASAN}

\section{Pemahaman Masyarakat Yosowilangun - Kabupaten Lumajang Tentang Koperasi Syariah}

Menurut Hamid, Abdul (2008:47) koperasi syariah merupakan koperasi yang aktivitas usahanya menghimpun dan menyalurkan dana dari/kepada anggota atau calon anggota dengan sistem mudhorabah (bagi hasil) atau murabahah (jual beli) yang dijamin sah menurut syari'ah dan tidak bertentangan dengan peraturan perundang-undangan negara Republik Indonesia, dan transaksi yang diterapkan dalam aktivitas BMT tidak mengandung unsur riba yang dilarang menurut syari'ah. Sejalan dengan teori di depan maka peneliti menemukan hasil penelitian terkait dengan pemahaman masyarakat di desa Yosowilangun Lor Kecamatan Yosowilangun Kabupaten Lumajang yang menunjukkan bahwa pemahaman masyarakat tentang koperasi syariah sebagian besar sudah cukup baik. Berikut beberapa cuplikan wawancara peneliti dengan pengelola dan anggota koperasi. Cuplikan pertama peneliti lakukan dengan pengelola koperasi yaitu Bapak A.H.B selaku kepala Koperasi Syariah Sidogiri Capem Yosowilangun sebagai berikut:

\begin{tabular}{|ll|}
\hline Peneliti & : Bagaimana Pemahaman Bapak tentang Koperasi Syariah ? \\
Informan & Koperasi Sidogiri ini ya termasuk lembaga keuangan \\
& $\begin{array}{l}\text { syariah yang sesuai dengan ajaran syariah dengan akad- } \\
\text { akad yang sudah ditentukan di BMT Sidogiri }\end{array}$ \\
\hline
\end{tabular}

Sumber : W/Inf 1/03 Okt 2019/84

Pemahaman yang seragam juga disampaikan oleh karyawan koperasi Sidogiri yang menduduki jabatan sebagai teller koperasi. Menurut bapak F, koperasi syariah dipahami dalam cuplikan berikut ini: 


$$
\begin{array}{ll}
\text { Peneliti } & \text { : } \\
\text { Inf ormagaimana pemahaman bapak tentang koperasi syariah? } & \text { : } \\
& \text { boperasi syariah adalah sebuah badan usaha yang } \\
& \text { melandaskan orang-orang atau badan usaha yang } \\
& \text { syariah atau bagi hasil dan berdasarkan atas azas } \\
& \text { kekeluargaan dan tanpa riba." }
\end{array}
$$

Sumber : W/Inf 2/08 Okt 2019/87

Lebih lanjut menurut informan lain yaitu bapak Z.I sebagai marketing di koperasi syariah Sidogiri Capem Yosowilangun memiliki pemahaman sebagai berikut:

$$
\begin{array}{ll}
\text { Peneliti } & \text { : } \\
\text { Informanaimana pemahaman bapak tentang koperasi syariah? } & : \text { "Koperasi syariah menurut pemahaman saya, lembaga } \\
& \text { keuangan yang melandaskan kegiatannya pada prinsip } \\
& \text { syariah dengan melalui akad kerjasama bagi hasil dan } \\
& \text { tanpa adanya riba." }
\end{array}
$$

Sumber : W/Inf 3/12 Okt 2019/90

Tidak jauh berbeda dengan pemahaman para pengelola, pemahaman anggota koperasi pun sudah cukup baik. Anggota yang menjadi bagian dari koperasi syariah sidogiri ini merasa sangat terbantu utamanya dalam meningkatkan usaha mandiri mereka. Berikut cuplikan pemahaman tentang koperasi syariah menurut para anggota.

$$
\begin{array}{ll}
\text { Peneliti } & \text { : Bagaimana pemahaman ibu tentang koperasi syariah? } \\
\text { Informan } & \text { : Koperasi yang sistemnya dengan tanpa sistem bunga karena } \\
& \text { melalui akad kerjasama yang sesuai dengan tuntunan syariah } \\
& \text { yang ada }
\end{array}
$$

Sumber: W/ Inf 4/4 November 2019/98

Berdasarkan wawancara tersebut dapat disimpulkan bahwa koperasi syariah adalah koperasi yang dalam menjalankan aktivitasnya sesuai dengan ajaran syariah melalui akad-akad kerjasama mudharabah, murabhahah, atau 
akad jual beli yang sesuai dengan tuntunan syariah dengan berprinsip bagi hasil serta tidak mengandung unsur riba. Pemahaman dari cuplikan wawancara di depan sesuai dengan teori Nur S. Buchori (2009:12) yang menyatakan bahwa koperasi syariah adalah usaha ekonomi yang terorganisir secara mantap, demokratis, otonom partisipatif, dan berwatak sosial yang operasionalnya meggunakan prinsip-prinsip yang mengusung etika moral dan memperhatikan halal atau haramnya sebuah usaha yang dijalankannya sebagaimana diajarkan dalam Islam.

Berdasarkan beberapa cuplikan hasil wawancara didepan serta teori yang relevan dapat disimpulkan bahwa pemahaman masyarakat tentang koperasi syariah sudah baik dan paham tentang koperasi syariah. Bentuk kepahaman masyarakat terhadap koperasi syariah ialah bahwa koperasi syariah adalah koperasi yang kegiatannya berlandaskan syariah dengan sistem bagi hasil dan tanpa adanya riba.

\section{Strategi Koperasi Syariah Sidogiri Capem Yosowilangun Kabupaten} Lumajang dalam Memberdayakan Masyarakat Ekonomi Lemah di Desa Yosowilangun-Lumajang

Menurut Blocher, Stout, Juras, \& Cokins (2013:15) strategi didefinisikan sebagai sebuah perencanaan yang memanfaatkan sumber daya untuk mencapai tujuan yang berkelanjutan didalam lingkungan yang kompetitif. Lebih lanjut Hitt, Ireland and Hoskisson dalam Afuah (2009:29) memaparkan bahwa strategi merupakan sebuah rangkaian komitmen dan tindakan yang terintegrasi serta terkoordinasi yang dibentuk untuk memanfaatkan kompetensi inti dari perusahaan guna meraih keunggulan kompetitif. Berkaitan dengan kedua paparan di depan, maka strategi koperasi syariah merupakan rangkaian tindakan yang memanfaatkan kekuatan dan sumber daya koperasi dalam mencapai tujuan dan target koperasi. 
Berkaitan dengan kajian teori didepan maka strategi koperasi sidogiri Capem Yosowilangun memiliki sebuah tujuan yang salah satunya memberdayakan ekonomi masyarakat lemah di desa Yosowilangun - Kabupaten Lumajang. Pemberdayaan merupakan sebuah upaya untuk membangun kemampuan masyarakat, dengan mendorong, memotivasi, membangkitkan kesadaran akan potensi yang dimiliki dan berupaya untuk mengembangkan potensi itu menjadi tindakan nyata (Haris, Abdul 2013:42). Berikut cuplikan hasil wawancara peneliti dengan pengelola koperasi syariah Sidogiri Capem Yosowilangun dalam memberdayakan masyarakat ekonomi lemah.

\begin{tabular}{|ll|}
\hline Peneliti & : Bagaimana strategi Koperasi Syariah Sidogiri Capem \\
& Yosowilangun dalam memberdayakan masyarakat yang memiliki \\
& ekonomi lemah? \\
Informan & :Kami melakukan sistem jemput bola kepada \\
& nasabah/anggota yang perekonomiannya lemah, kemudian mereka \\
& kita bimbing untuk berbisnis atau berwirausaha atau berketrampilan \\
& yang nantinya dengan hal tersebut dapat menjadikan \\
& nasabah/anggota tersebut dapat memperbaiki perekonomiannya". \\
\hline
\end{tabular}

Sumber : W1/INF1/03 Okt /P2/85

Lebih lanjut informan kedua yaitu bapak F sebagai teller di koperasi sidogiri Yosowilangun menyampaikan bentuk strategi koperasi dalam cuplikan wawancara berikut.

\begin{tabular}{|ll}
\hline Peneliti & : Bagaimana peran Koperasi Syariah Sidogiri Capem \\
& Yosowilangun dalam melakukan pemberdayaan masyarakat \\
& ekonomi lemah? \\
Informan & : "Selain dengan produk-produk diatas, karyawan-karyawan yang \\
& ada di BMT mencari nasabah yang perekonomiannya termasuk \\
& dalam masyarakat kurang atau tidak mampu, kemudian setelah itu \\
& kita berusaha agar masyarakat tersebut bisa mempunyai usaha \\
& sehingga dengan usaha tersebut dapat memperbaiki \\
& perekonomiannya".
\end{tabular}

Sumber : W2/INF2/03 Okt /P1/88 
Berdasarkan cuplikan wawancara didepan, maka strategi utama yang pihak koperasi lakukan untuk memberdayakan masyarakat ekonomi lemah yaitu dengan melakukan upaya jemput bola terhadap anggota/nasabah yang memiliki kondisi perekonomian lemah dengan cara diberikan wawasan untuk

\begin{tabular}{|c|c|}
\hline Peneliti & $\begin{array}{l}\text { : Produk apa yang ibu pilih di Koperasi Syariah Sidogiri Capem } \\
\text { Yosowilangun? }\end{array}$ \\
\hline Informan & : "Tabungan syariah". \\
\hline Peneliti & : Apa yang menjadi alasan anda memilih produk tersebut? \\
\hline Informan & : "Karena uang tabungannya itu bisa diambil kapan saja". \\
\hline Peneliti & $\begin{array}{l}\text { : Bagaimana rencana anda sehingga dapat menguatkan } \\
\text { perkonomian anda?? }\end{array}$ \\
\hline Informan & $\begin{array}{l}\text { : "Rencana kedepannya itu, nantinya uang tabungan tersebut dapa } \\
\text { dijadikan modal usaha yang sudah saya rintis. tentunya mungkin } \\
\text { masih perlu tambahan modal lagi dari koperasi syariah. jadi } \\
\text { mungkin nanti akan melakukan akad kerjasama di koperasi dalam } \\
\text { meminjam uang untuk memenuhi kebutuhan modal usaha saya." }\end{array}$ \\
\hline
\end{tabular}

Sumber : W/Inf 4/14 November 2019 /93-94

Berdasarkan hasil wawancara tersebut dapat disimpulkan bahwa dalam pemberdayaan masyarakat ekonomi lemah salah satunya adalah dengan memilih produk tabungan umum syariah (yang setoran dan penarikannya dapat dilakukan setiap saat sesuai kebutuhan anggota atau nasabah), dimana dengan produk tersebut maka uang yang terkumpul dapat digunakan untuk keperluan modal usaha. Jika modal usaha yang akan digunakan dari tabungan syariah tidak mencukupi, maka ibu C.S akan melakukan akad kerjasama berupa pinjaman modal, sehingga dengan tambahan modal tersebut dapat menjadikan usahanya lebih baik lagi. Alasan yang tidak jauh berbeda dipaparkan bapak F.A. tentang produk yang dipilih, sebagai berikut. 


\begin{tabular}{|ll|}
\hline Peneliti & : Produk apa yang anda pilih di Koperasi Syariah Sidogiri Capem \\
& Yosowilangun? \\
Informan & : "Produk akad jual-beli". \\
Peneliti & : Apa yang menjadi alasan anda memilih produk tersebut? \\
Informan & : "Dengan produk tersebut yaaa... saya dapat keringanan dalam \\
& $\begin{array}{l}\text { pembayaran barang yang kita beli, karena dengan dapat dibayar } \\
\text { denga mencicil". }\end{array}$ \\
Peneliti & : Bagaimana rencana anda sehingga dapat menguatkan \\
& perkonomian anda?? \\
Informan & :Rencananya dengan kendaraan yang saya beli memlalui akad \\
& $\begin{array}{l}\text { jual beli di koperasi syariah, maka kendaraan tersebut dapat saya } \\
\text { gunakan untuk melakukan aktivitas pekerjaan saya sebagai } \\
\text { pedagang buah." }\end{array}$ \\
\hline
\end{tabular}

Sumber : W5/INF5/03 Okt /P1/95-96

Berdasarkan cuplikan wawancara di depan maka anggota koperasi merasa diuntungkan dengan produk jual-beli yang ada di koperasi syariah karena proses pelunasan barang yang dibeli anggota menjadi lebih terjangkau. Bapak F.A merasa terbantu untuk melakukan aktivitas ekonomi sehari-hari sebagai pedagang buah melalui produk akad Rahn yaitu akad pemberian pinjaman dari BMT untuk anggota atau nasabah yang disertai dengan penyerahan agunan barang milik anggota, bila anggota tidak bisa melunasi pinjamannya maka barang agunan tersebut sebagai pelunasan pinjaman.

Cuplikan - cuplikan wawancara di depan menunjukkan bahwa anggota/nasabah mampu meningkatkan aktivitas ekonomi mereka sehingga banyak dari masyarakat merasa terbantu dengan adanya koperasi syariah melalui berbagai program yang ada di koperasi syariah. Pemberdayaan masyarakat ekonomi lemah dilakukan dengan cara menumbuhkan dan mengembangkan potensi ekonomi yang ada dimasyarakat secara maksimal dalam bentuk pendirian atau pengembangan usaha pada kalangan masyarakat ekonomi lemah. Hasil penelitian ini memiliki relevansi dengan penelitian yang dilakukan oleh Lindia Watie tahun 2018, dengan judul penelitian Peran Koperasi Syariah BMT Bumi Dalam Meningkatkan Kualitas Usaha Mikro dengan 
hasil penelitian yang menunjukkan bahwa BMT Bumi telah menjalankan perannya secara umum sebagai koperasi syariah yang mampu membuat kegiatan ekonomi dan sosial anggotanya yang merupakan warga sekitar masjid menjadi lebih baik dan sejahtera, sedangkan jenis-jenis peran aktif yang telah dilakukan oleh BMT Bumi dalam peningkatan kualitas usaha mikro.

\section{KESIMPULAN}

\section{Kesimpulan}

Pemahaman masyarakat terhadap koperasi syariah sudah baik dimana masyarakat mampu menjelaskan bahwa bentuk pengelolaan koperasi syariah yaitu koperasi yang dalam menjalankan aktivitasnya sesuai dengan ajaran syariah melalui akad-akad kerjasama mudharabah, murabhahah, atau akad jualbeli, melalui prinsip bagi hasil dan didalamnya tidak mengandung unsur riba.

Strategi koperasi syariah dalam memberdayakan masyarakat ekonomi lemah ditunjukkan dengan melakukan upaya jemput bola terhadap anggota/nasabah yang perekonomiannya lemah untuk berbisnis atau berwirausaha sehingga dengan usaha atau bisnis tersebut dapat memunculkan atau mengembangkan usaha ekonomi dari kalangan masyarakat ekonomi lemah sehingga dengan usaha tersebut meningkatkan perekonomian anggota.

\section{Saran}

Bagi Prodi Pendidikan Ekonomi STKIP PGRI Lumajang diharapkan mampu memberikan referensi yang berkaitan dengan strategi koperasi syariah dalam memberdayakan masyarakat ekonomi lemah.

Bagi pengelola koperasi dihararapkan dapat meningkatkan pelayanan kepada masyarakat sehingga kedepan mampu memperkenalkan ekonomi syariah kepada masyarakatt lebih luas.

Bagi anggota koperasi diharapkan mampu memilih produk koperasi sesuai kebutuhannya dalam upaya meningkatkan perekonomian mereka yang 
diharapkan dapat ikut andil dalam mengangkat dan memperkenalkan ekonomi syariah kepada masyarakat lebih luas.

\section{DAFTAR RUJUKAN}

Blocher, David E Stout dan Gery Cokins. 2013. Manajemen Biaya Penekanan Strategis Buku 1 Edisi kelima. Jakarta: Salemba Empat.

Buchori, Nur S. 2010. Koperasi Syariah. Masmedia Buana Pustaka: Sidoarjo

Hamid, Abdul. Koperasi Syariah. 2009. Masmedia Buana Pustaka: Sidoarjo

Haris, Abdul. Indikator Kesejahteraan Rakyat. 2013. Badan Pusat Statistik: Makassar

Maryati, Kun. 2005. Ilmu Pengetahuan Sosial Ekonomi, Edisi I. Departemen Pendidikan Nasional: Jakarta

Rukminto, Adi isbandi. Ilmu Kesejahteraan Sosial dan Pekerjaan Sosial. 2005. FISIP UI PRESS: Depok.

Sumiyanto, Ahmad. 2008. Menuju Koperasi Modern (Panduan untuk Pemilik, Pengelola dan Pemerhati Baitul maal wat Tamwii dalam format Koperasi). Debeta :Yogyakarta 